\title{
APLICAÇÃO DE GENES MARCADORES EM ESTUDOS DE ECOLOGIA MICROBIANA COM ENNFASE NO SISTEMA GUS
}

\author{
APPLICATIONS OF MARKERS GENES ON ECOLOGIC \\ MICROBIAL STUDIES WITH ENPHASIS ON GUS SYSTEM
}

\author{
Fábio Martins Mercante ${ }^{1}$ Norma Gouvêa Rumjanek $^{2}$ Avílio Antonio Franco $^{3}$
}

\section{- REVISÃO BIBLIOGRÁFICA -}

\section{RESUMO}

\begin{abstract}
Muitos aspectos ecológicos envolvidos nas interações entre espécies leguminosas e estirpes de rizóbio têm sido facilmente entendidos com o emprego de técnicas que utilizam genes marcadores. A introdução de um gene marcador específico tem se mostrado altamente viável para análises dessas interações. Os genes marcadores são capazes de codificar para produtos que podem ser facilmente identificados ou medidos, especialmente, enzimas que podem atuar em diferentes substratos, fornecendo produtos coloridos ou fluorescentes facilmente detectáveis. De uma maneira geral, os genes marcadores têm sido utilizados em diferentes aspectos da ecologia microbiana, como nos estudos de competição entre estirpes de rizóbio, expressão de genes simbióticos, colonização da rizosfera e raízes, entre outros. Em todos esses estudos, os genes repórteres precisam ser introduzidos no genoma alvo através de um plasmídeo ou por inserção cromossomal. Nesta revisão, são enfatizados, principalmente, os diversos usos e aplicações de genes marcadores nos estudos de ecologia microbiana, com ênfase no sistema GUS ( $\beta$ glucuronidase).
\end{abstract}

Palavras-chave: gene marcador, ecologia microbiana, gene gus, sistema GUS, $\beta$ - glucuronidase, Rhizobium, simbiose.

\section{SUMMARY}

Many of the ecological aspects involved with the interactions between legume species and rhizobia strains have been made easily to understood with the use of reporter gene techniques. The introduction of a specific reporter gene in an organism has shown to be highly efficient to analyze such interactions. These reporter genes generally code for products that can be easily identified or measured, mainly enzymes that can act on a variety of substrates, supplying colored or fluorescent detectable products. In general, the marker genes have been used in different aspects of microbial ecology, as in the competition studies among rhizobia strains, symbiotic gene expression, rhizosphere and root colonization, among others. In all studies, the marker genes need to be introduced into the genome by a plasmid or through a chromosomal insert. The present review focus, mainly, on the diverse use and applications of marker genes on ecological microbial studies with emphasis on the GUS gene system ( $\beta$-glucuronidase).

Key words: reporter gene, microbial ecology, marker gene, gus gene, GUS system, $\beta$ - glucuronidase, rhizobia, symbiosis.

\section{CONSIDERAÇÕES GERAIS}

As principais barreiras encontradas nos estudos de ecologia microbiana envolvem a detecção e/ou identificação de organismos específicos. Muitas vezes, algumas metodologias como sorologia e testes de resistência a antibióticos, que são marcas fenotípicas, são descritas como marcadores moleculares para enfatizar que as novas metodologias, baseadas na biologia molecular, podem ser vistas como uma extensão dos procedimentos já existentes. Esses métodos mais tradicionais usados na identificação dos organismos utilizam moléculas endógenas como marcadores, tais como enzimas metabólicas características (WILSON, 1995).

Entretanto, esses métodos tradicionais não permitem uma avaliação satisfatória da comunidade

\footnotetext{
${ }^{1}$ Engenheiro Agrônomo, PhD, Pesquisador da Embrapa/CPAO, Centro de Pesquisa Agropecuária do Oeste, Rodovia BR 163, Km 253, CP 661, 79804-970, Dourados, MS. Fax: ++55-67-421-0811. E-mail: mercante@ cpao.embrapa.br. Autor para correspondência.

${ }^{2}$ Farmacêutica, PhD., Pesquisadora da Embrapa /CNPAB-Centro Nacional de Pesquisa de Agrobiologia, Seropédica, RJ.

${ }^{3}$ Engenheiro Agrônomo, PhD., Pesquisador da Embrapa /CNPAB-Centro Nacional de Pesquisa de Agrobiologia, Seropédica, RJ. Recebido para publicação em 16.04.99. Aprovado em 29.09.99
} 
microbiana, devido a problemas básicos de análise, como por exemplo, a falta de um meio de cultura dito universal para contagem da população total de microrganismos presentes num determinado "habitat" (REIS, 1996). Além disso, sofrem outras limitações, apresentando-se trabalhosas ou imprecisas (WILSON, 1995; WILSON et al., 1996; SESSITSCH et al., 1998).

Existe, portanto, a necessidade de utilização de métodos mais sensíveis e seguros de detecção e quantificação de organismos em determinada comunidade microbiana. Nesse sentido, técnicas desenvolvidas mais recentemente, baseadas na biologia molecular, oferecem muitas vantagens, como o aumento da precisão e/ou facilidade no processo de detecção (SESSITSCH $\boldsymbol{e t}$ al., 1998; WILSON et al., 1994).

Entre os principais métodos desenvolvidos mais recentemente, estão aqueles envolvidos na detecção de padrões característicos e seqüências de ácidos nucléicos (DNA e RNA) e, entre outros, o método que possibilita a identificação da atividade de um gene específico através da introdução dos chamados "genes marcadores introduzidos".

As diferentes técnicas de detecção de ácidos nucléicos disponíveis se baseiam na detecção de seqüências de DNA específicas, determinadas por hibridização (SAYLER et al., 1992), ou na amplificação de sequiências características, seguidas, quando necessário, por detecção através de hibridização (STEFFAN \& ATLAS, 1991). As técnicas baseadas nos ácidos nucléicos são, em muitos casos, complementares às técnicas que empregam um gene marcador (WILSON, 1995). As desvantagens dessas técnicas, quando comparadas com a utilização dos "genes marcadores introduzidos", estão no fato de serem mais complexas tecnicamente, especialmente quando se pretende alcançar um maior nível de sensibilidade (SAYLER $\boldsymbol{e t}$ al., 1992; STEFFAN \& ATLAS, 1991).

Diversos marcadores moleculares em nível de DNA têm sido empregados na identificação de bactérias e em estudos sobre filogenia de rizóbio, competitividade e ecologia microbiana, em geral. Entre esses principais marcadores, destaca-se o PCR ("polymerase chain reaction"), que permite a replicação de sequiências definidas de DNA, de modo a amplificar seqüências de genes (SAIKI $\boldsymbol{e t}$ al., 1988). Outros métodos que ganharam impulso nos últimos anos foram o RFLP (polimorfismo pelo tamanho dos fragmentos de restrição) (LAGUERRE $\boldsymbol{e t}$ al., 1992), o RAPD (polimorfismo do DNA amplificado aleatoriamente) (CAETANO-ANOLLÉS $\boldsymbol{e t} \boldsymbol{a l}$. , 1992) e o sequienciamento do DNA ribossomal $16 \mathrm{~S}$ (YOUNG et al., 1991). Contudo, nesta revisão, será enfocada apenas a utilização dos genes marcadores, com ênfase no sistema do gene repórter GUS.

\section{DIFERENTES GENES MARCADORES UTILIZADOS NA ECOLOGIA DE RIZÓBIO}

O estudo de muitos aspectos ecológicos envolvidos na interação entre espécies leguminosas e estirpes de rizóbio tem sido amplamente facilitado com o emprego de técnicas que utilizam genes marcadores. O uso de um "gene marcador específico", que pode ser introduzido no organismo sob estudo, tem se mostrado altamente viável para análises dessas interações de rizóbio com leguminosas, sem as desvantagens mencionadas anteriormente, nos métodos de detecção de ácidos nucléicos.

Os genes marcadores codificam produtos que podem ser facilmente identificados ou medidos, especialmente enzimas que podem atuar em diferentes substratos, fornecendo produtos coloridos ou fluorescentes, facilmente detectáveis (JEFFERSON, 1989; WILSON, 1995). De uma maneira geral, a introdução de tais genes marcadores facilita o monitoramento de estirpes bacterianas específicas.

Diversas aplicações de uso dos genes marcadores têm sido mencionadas nos estudos de ecologia de bactéria e outros microrganismos que interagem com plantas. Entre essas aplicações estão os estudos de competição de rizóbio. Dessa forma, esta metodologia que utiliza os genes marcadores permite a avaliação de competição com sistemas radiculares intactos, nos quais se identificam os nódulos formados pela estirpe inoculada, por meio de uma coloração distinta (STREIT et al., 1992).

Os genes marcadores podem, ainda, ser usados como "repórteres" ("reporter genes"), ligados aos promotores do gene, que respondem a uma variedade de sinais ambientais (WILSON et al., 1994).

Os genes repórteres são instrumentos da biologia molecular de grande importância, com uma ampla diversidade de aplicações. Eles podem ser usados para substituir um gene estrutural de interesse e, portanto, atuar como repórter da expressão do gene, através da criação de uma "fusão de gene". Em estudos da ecologia microbiana, os genes repórteres são utilizados para facilitar a detecção de estirpes de bactérias marcadas (WILSON, 1995).

Estudos atuais de biologia molecular têm procurado cada vez mais o entendimento da regulação da expressão dos genes. Os fatores que atuam em tal regulação vêm sendo melhor estudados com o uso de "fusões de gene". As fusões de gene podem ser definidas como construções de DNA, formadas in vitro ou in vivo, que resultam em seqüências codificadoras de um gene repórter, sendo transcrito e/ou 
traduzido na direção de seqüências controladoras de outro gene, denominado "controlador" (JEFFERSON, 1987).

As fusões genéticas podem ser de dois tipos gerais, que compreendem as "fusões transcricionais" e "fusões translacionais", com variações dentro de cada tipo. As fusões transcricionais são definidas como aquelas em que todas as seqüências codificadoras da proteína são derivadas do gene repórter, sem participação do controlador. Assim, embora o mRNA produzido possa consistir de seqüências, tanto do gene controlador quanto do gene repórter, a proteína sintetizada será codificada somente pelo gene repórter. Por outro lado, as fusões translacionais são definidas como sendo aquelas em que o polipeptídeo produzido é o resultado de uma informação codificadora, proporcionada tanto pelo gene repórter quanto pelo gene controlador (JEFFERSON, 1987).

O controle da atividade do gene pode ser manifestado em diversos níveis, incluindo o início da transcrição ou tradução, o processamento, transporte ou degradação do mRNA ou da proteína (JEFFERSON, 1987). O uso de fusões genéticas adequadas pode simplificar a análise desse processo complexo.

Estudos recentes têm mostrado o uso de genes marcadores controlados por novas seqüências promotoras de DNA, que respondem a sinais específicos do ambiente. Nesse caso, usa-se um gene marcador sem promotor e seleciona-se por padrões de expressão do gene marcador, que é controlado por seqüências promotoras adjacentes ao ponto de inserção na bactéria receptora (WILSON, 1995). Por exemplo, têm sido identificadas seqüências que regulam a expressão do gene marcador em resposta a componentes de exsudato radicular (LAM et al., 1990), ou à disponibilidade de fosfato (DE WEGER et al., 1994).

\section{Introdução do gene marcador em estirpes de rizóbio}

Segundo WILSON (1995), o gene marcador pode ser introduzido na bactéria receptora de duas formas diferentes: através de um plasmídeo, que é capaz de se duplicar, pelo processo de replicação, como um elemento autônomo na bactéria receptora, ou como parte do DNA que fica integrado ao cromossomo da bactéria. A inserção de tais genes marcadores no genoma alvo pode ser ao acaso ou dirigida, permitindo avaliar a regulação de determinados genes (REUBER et al., 1991).

A introdução do gene marcador como uma inserção direta no genoma do receptor pode ser alcançada através do uso de elementos de transposi- ção ("transposons"), conforme demonstrado por HERRERO et al. (1990) e DE LORENZO et $\boldsymbol{a l}$. (1990). Os elementos de transposição que se movem dentro do genoma, sem que seja necessário homologia, podem ser usados para conferir resistência a antibióticos, cujo mecanismo difere dos naturalmente existentes na maioria das bactérias. A introdução do gene marcador no cromossoma da bactéria receptora oferece uma vantagem significativa, tendo em vista que a inserção pode ser tão estável quanto os outros genes cromossomais. Uma desvantagem potencial é que qualquer inserção no DNA genômico pode, ainda que a uma freqüência muito baixa, causar uma mutação no gene de importância no processo que está sendo estudado (WILSON, 1995).

O uso de plasmídeos para clonagem do gene marcador pode apresentar algumas desvantagens, uma vez que não são completamente estáveis (WEINSTEIN et al., 1992), e a sua perda significaria, também, a perda do gene marcador; além disso, poderia transferir-se a outras bactérias no solo (WILSON et al., 1996). Portanto, torna-se mais seguro a incorporação de genes clonados no cromossomo.

A inserção no cromossomo pode ser obtida por recombinação, se o DNA doador e o DNA do cromossoma apresentarem seqüências homólogas (ACUNA et al., 1987). Com base nos elementos transponíveis Tn5 e Tn10, foi desenvolvido um procedimento simples para clonagem e inserção de genes externos no cromossoma de bactérias gramnegativas (HERRERO et al., 1990; DE LORENZO et al., 1990). Uma coleção dos chamados minielementos de transposição ("mini-transposon"), localizados em plasmídeos suicidas, tem sido construída para simplificar o processo de marcação. $\mathrm{O}$ plasmídeo é mantido na estirpe de $\boldsymbol{E}$. coli $\operatorname{S} 17-1(\lambda$ pir) e pode ser transferido dessa estirpe para o rizóbio, por conjugação. A conjugação é obtida pela mistura das estirpes doadora e receptora, crescendo num meio não-seletivo. As expressões dos genes tra no cromossoma de $\boldsymbol{E}$. coli, e do gene mob no plasmídeo, são necessárias para o processo de conjugação. O gene marcador será transferido quando houver crescimento de células transconjugantes num meio que não pode ser usado pelas células da estirpe doadora e da receptora (SESSITSCH et al., 1998).

O plasmídeo de entrega ("suicida") não pode se manter nas células receptoras de rizóbio, porque sua replicação depende de proteínas específicas de E. coli. Não obstante, o mini-elemento de transposição ("mini-transposon") pode mover-se do plasmídeo de entrega até uma nova localização no genoma do hospedeiro, inserindo-o assim no cromossoma do rizóbio (WILSON et al., 1996). Uma 
característica especial do mini-elemento de transposição é que o gene responsável pelo evento da transposição é deixado no plasmídeo de entrega e não é levado ao cromossoma bacteriano, o que reduz a probabilidade de transposições posteriores do gene marcador introduzido, aumentando a sua estabilidade (DE LORENZO et al., 1990).

\section{O sistema do gene repórter GUS}

O sistema de fusão do gene gus ( $\beta$ glucuronidase) está sendo amplamente utilizado como um gene repórter em estudos de biologia molecular de plantas (JEFFERSON et al., 1987), uma vez que a atividade GUS não se encontra presente no tecido vegetal. Além disso, tem se mostrado altamente adequado aos estudos de interação entre plantas e microrganismos, devido à ausência de atividade endógena de GUS em muitas bactérias de importância agrícola, como Rhizobium, Bradyrhizobium, Agrobacterium, Azospirillum e Pseudomonas (WILSON et al., 1996).

O gene gusA (também designado como gene uidA), codificador da enzima $\beta$-glucuronidase, foi originalmente isolado de $\boldsymbol{E}$. coli (JEFFERSON $\boldsymbol{e} \boldsymbol{t}$ al., 1986). Em E. coli, a atividade $\beta$-glucuronidase não é expressa constitutivamente e o gene gusA é parte de um operon (WILSON et al., 1992).

O gene gusA oxida o substrato "X-glucA" (5-bromo-4-cloro-3-indolil- $\beta$-D-glucuronídeo) e pode ser facilmente monitorado, usando uma grande variedade de glucuronídeos (JEFFERSON, 1987), fornecendo como produto um composto insolúvel de cor azul. Recentemente, um novo gene repórter (celB), análogo ao gene gusA, mas que usa substratos menos custosos, tem sido usado como marcador em estudos de ecologia de rizóbio. O substrato "Magenta-glucA" (5-bromo-6-cloro-3-indolil- $\beta$-D-glucuronídeo) resulta em precipitados de cor magenta (WILSON, 1995).

Dessa forma, o gene marcador gusA torna-se bastante apropriado em diversos estudos da ecologia microbiana. Os estudos iniciais com uso de gusA como gene marcador em bactérias eram amplamente restritos à análise de regulação da expressão de genes (SHARMA \& SIGNER, 1990; VAN DEN EEDE $\boldsymbol{e t}$ al., 1992). WILSON $\boldsymbol{e} \boldsymbol{t} \boldsymbol{a l}$. (1991) demonstraram a possibilidade de se detectar a infecção de pêlos radiculares e ocupação nodular. Em estudos de ocupação nodular, a detecção de estirpes marcadas é extremamente fácil de se realizar: nódulos induzidos por estirpes marcadas com o gene gusA são alterados a uma coloração azul quando a raiz, após ser lavada, é incubada em um meio com tampão fosfato contendo o substrato GUS "X-glcA", ou a uma coloração magenta quando é incubada com "Magenta-glucA" (WILSON et al., 1995). Esse procedimento elimina a necessidade do corte de nódulos para se proceder o isolamento de bactérias, etapa geralmente requerida em todas as demais técnicas. A utilização do gene gusA, em estudo de competição para nodulação do feijoeiro (Phaseolus vulgaris L.), foi apresentada por STREIT et al. (1992). Neste estudo, foi comparada a capacidade de dezessete estirpes de $\boldsymbol{R}$. leguminosarum bv. phaseoli e três estirpes de $\boldsymbol{R}$. tropici na competição para nodulação, usando a coinoculação com um derivado marcado com o gene gusA da estirpe KIM5s de $\boldsymbol{R}$. leguminosarum bv. phaseoli. Os experimentos de competição foram realizados em níveis de pH 5,2 e 6,4. A habilidade competitiva observada foi variável, desde $4 \%$ para a estirpe menos competitiva até $96 \%$ para a mais competitiva. As estirpes de $\boldsymbol{R}$. tropici mostraram baixa ocupação nodular a pH 6,4 ; porém, sua habilidade competitiva aumentou, consideravelmente, em $\mathrm{pH}$ mais baixo.

Contudo, para utilizar o gene marcador gusA torna-se necessário, primeiramente, a sua introdução na estirpe de rizóbio que se pretende estudar, conforme mencionado anteriormente. Isso pode ser obtido mediante um "sistema de introdução de um elemento de transposição" ("transposon delivery system"), que insere o gene marcador no cromossomo da estirpe de rizóbio receptora. O elemento de transposição ("transposon") é fornecido por uma estirpe doadora de $E$. coli, que é acoplada à bactéria receptora. Uma vez que esta fusão de genes tenha ocorrido na bactéria, a expressão do gene repórter gus sinaliza a atividade do outro gene (WILSON et al., 1992).

Cada elemento de transposição contém um gene cassete ("cassette gene") que consiste do mesmo gene marcador com seqüências adjacentes de "promotores", que regulam a expressão do gene em resposta a sinais ambientais. Portanto, o gene cassete consiste de dois elementos: o gene estrutural em si; neste caso, o gene gusA codificador da GUS- e as sequiências de DNA que regulam quando e onde o gene estrutural é expresso, usualmente referido como o promotor (WILSON, 1995).

A escolha de promotores que respondem a diferentes sinais ambientais fornecerá informação sobre a bactéria num determinado ambiente, ou, inversamente, sobre o ambiente em si (WILSON, 1995). Para fins de atender a questões específicas da ecologia de rizóbio, diferentes genes cassetes têm sido desenvolvidos, consistindo do gene gusA como marcador e diferentes seqüências regulatóriaspromotores (Tabela 1).

Nos estudos de competição de estirpes de rizóbio, por exemplo, esses elementos de transposi- 
Tabela 1 - Alguns elementos de transposição disponíveis e suas aplicações (Adaptado de Wilson, 1995).

\begin{tabular}{|c|c|c|c|}
\hline $\begin{array}{l}\text { Elemento de transposição } \\
\text { GUS }\end{array}$ & $\begin{array}{l}\text { Tipo de } \\
\text { promotor }\end{array}$ & Descrição & Uso \\
\hline mTn5SSgusA 10 & Repressor & $\begin{array}{l}\text { O gene gus } A \text { é reprimido normalmente } \\
\text { pelo produto do gene } l a c I \text {, mas pode ser } \\
\text { induzido usando IPTG (isopropil- } \beta-D \\
\text { tiogalactosida) }\end{array}$ & $\begin{array}{l}\text { Estudos de ecologia de rizóbio em solo } \\
\text { e rizosfera, e também em estudos de } \\
\text { ocupação nodular }\end{array}$ \\
\hline $\begin{array}{l}\text { mTn5SSgusA11 } \\
\text { ou } \\
\text { mTn5SSgusA20 }\end{array}$ & Constitutivo & $\begin{array}{l}\text { O gene gusA é expresso constitutiva- } \\
\text { mente em bactéria de vida livre }\end{array}$ & $\begin{array}{l}\text { Estudos de ecologia de rizóbio em } \\
\text { solo e rizosfera }\end{array}$ \\
\hline $\begin{array}{l}\text { mTn5SSgusA30 } \\
\text { ou } \\
\text { mTn5SSgusA31 }\end{array}$ & Simbiótico & $\begin{array}{l}\text { O gene gusA é expresso somente em } \\
\text { nódulos fixadores de } \mathrm{N}_{2} \text { ativos }\end{array}$ & Estudos de ocupação nodular \\
\hline mTn5SSgusA40 & Sem promotor & $\begin{array}{l}\text { A expressão do gene gusA é dependente } \\
\text { do controle genético do hospedeiro }\end{array}$ & $\begin{array}{l}\text { Criação de estirpes que produzem GUS } \\
\text { em resposta a sinais ambientais especí- } \\
\text { ficos, como, p. ex., em resposta a } \\
\text { exsudatos radiculares }\end{array}$ \\
\hline
\end{tabular}

ção permitem a avaliação em, pelo menos, três fases diferentes: na sobrevivência saprofítica como organismos de vida livre no solo, na competição para colonizar a rizosfera e, por fim, no resultado final em termos de porcentagem de ocupação dos nódulos (WILSON et al., 1996). Além dessas avaliações, elementos de transposição foram desenvolvidos também para estudos de colonização da rizosfera de outras bactérias associadas com plantas, como, por exemplo, Azospirillum. Dessa forma, o sistema GUS tem sido usado para observar as locações físicas de bactérias associadas com plantas (CHRISTIANSENWENIGER \& VANDERLEYDEN, 1993; HUREK et al., 1994).

Muitas vezes, as infecções misturadas, que proporcionam dupla ocupação nodular, não são consideradas em estudos de competição, pelo fato das metodologias apresentarem-se muito laboriosas quando se emprega os métodos sorológicos ou de resistência a antibiótico. Num estudo com Rhizobium tropici marcado com gusA, foi possível determinar a dupla ocupação pelo exame direto do padrão de coloração dos nódulos (WILSON et al., 1996).

Nos estudos de interação simbiótica entre o feijoeiro (Phaseolus vulgaris L.) e estirpes de Rhizobium tropici, $R$. etli e $R$. leguminosarum bv. phaseoli, foram realizadas diversas avaliações da expressão dos genes da nodulação de diferentes estirpes bacterianas, contendo a fusão nodA::gusA. Em relação ao efeito inibitório do nitrogênio combinado na nodulação do feijoeiro, o emprego de genes marcadores tem contribuído para o entendimento do controle da nodulação. Nesse contexto, resultados experimentais obtidos por MERCANTE $\boldsymbol{e} \boldsymbol{t} \boldsymbol{a l}$. (1995) e STRALIOTTO $\boldsymbol{e} \boldsymbol{t} \boldsymbol{a l}$. (1995) demonstraram que a presença de nitrogênio mineral não inibiu a expressão dos genes nod $A B C$ de estirpes de Rhizobium tropici, $\boldsymbol{R}$. etli $e \quad \boldsymbol{R}$. leguminosarum bv. phaseoli, apesar da nodulação de duas cultivares de feijoeiro terem sido inibidas, mesmo em níveis baixos de nitrogênio adicionados.

Em outros estudos, quando exsudatos de sementes de feijoeiro e Mimosa flocculosa foram combinados e utilizados como indutores dos genes da nodulação, observaram-se aumentos sinergísticos significativos na expressão dos genes nod tanto de estirpes de $\boldsymbol{R}$. tropici quanto de $\boldsymbol{R}$. etli (MERCANTE, 1997; MERCANTE \& FRANCO, 1999). Esses resultados evidenciam a importância dos genes marcadores em estudos de ecologia microbiana através da regulação da expressão do gene marcador em resposta a sinais ambientais específicos.

Contudo, o sistema de transposição do gene gusA pode ser utilizado para marcar e, dessa maneira, estudar praticamente todas as estirpes de rizóbio e outras bactérias associadas a plantas.

\section{Outros sistemas de genes marcadores}

Vários outros sistemas marcadores, além do gene repórter gus, têm sido desenvolvidos para estudos da ecologia do rizóbio. O gene lacZ, codificador da enzima $\beta$-galactosidase, por exemplo, tem sido usado para estudar o processo de infecção nodular por Rhizobium (BOIVIN et al., 1990) e para 
estudos de colonização radicular por Azospirillum (KATUPITIYA et al., 1995). Esse gene pode ser detectado através da obtenção de um produto insolúvel de cor azul, na presença de "X-gal" (5-bromo-4cloro-3-indolil- $\beta$-D-galactosida), que é o substrato da enzima (DRAHOS et al., 1986). Porém, tanto o rizóbio quanto as plantas possuem a atividade $\beta$ galactosidase endógena, necessitando, assim, da aplicação de técnicas que diferenciem esta atividade endógena da atividade $\beta$-galactosidase adquirida, como, por exemplo, a utilização de variações de temperatura na amostra para inativar a enzima endógena (WILSON et al., 1996; REIS, 1996). LAM et al. (1990) utilizaram fusões $l a c Z$ para isolar promotores que respondem a exsudatos da rizosfera, e tais marcadores poderiam, então, ser usados para analisar a resposta dos exsudatos na colonização radicular.

Outros sistemas de marcadores disponíveis incluem o gene $x y l E$, que codifica para a atividade da enzima catecol-2-3 dioxigenase e o gene luxA, codificador para o catabolismo do naftaleno, produzindo uma bioluminescência (WILSON, 1995).

\section{CONSIDERAÇÕES FINAIS - Perspectivas}

Estudos atuais de biologia molecular têm procurado, cada vez mais, o entendimento da regulação da expressão dos genes. Neste contexto, o uso de genes marcadores controlados por novas seqüências promotoras de DNA tem sido ainda mais intensificado, facilitando a detecção de estirpes de bactéria em estudos ecológicos. O gene repórter gus tem sido altamente eficiente nos estudos envolvendo interações planta-microrganismos, considerando que uma estirpe marcada pode ser detectada através de métodos colorimétricos simples. Devido à simplicidade de sua metodologia, o Laboratório de Biotecnologia e Agricultura da FAO/IAEA desenvolveu um "kit do gene marcador gus", visando facilitar a sua utilização por pesquisadores que não estejam familiarizados com tal metodologia.

A principal vantagem do GUS, sobre os outros sistemas de gene marcador, é a sua ausência em plantas e bactérias, o que permite sua eficiente utilização em estudos envolvendo a bactéria na rizosfera e em associações simbióticas com plantas.

Contudo, deve-se considerar que o uso de genes marcados no campo está restrito pela legislação brasileira referente à liberação de organismos geneticamente modificados. A Lei de Biossegurança $\mathrm{N}^{\mathrm{o}} 8.974$, de 05 de janeiro de 1995, em vigor, estabelece normas para o uso das técnicas de engenharia genética e liberação, no ambiente, de organismos geneticamente modificados. Assim, o uso desse método de detecção no Brasil, atualmente, é recomendado apenas em estudos de laboratório e casa de vegetação, recomendando-se que todos os materiais contaminados (vidros, meios de cultura, solo, etc.) sejam autoclavados.

\section{REFERÊNCIAS BIBLIOGRÁFICAS}

ACUNA, G., ALVAREZ-MORALES, A., HAHN, M., et al. A vector for site-directed, genomic integration of foreign DNA into soybean root-nodule bacteria. Plant Molecular Biology, Dordrecht, v.9, p.41-50, 1987.

BOIVIN, C., CAMUT, S., MALPICA, C.A., et al. Rhizobium meliloti genes encoding catabolism of trigonelline are induced under symbiotic conditions. Plant Cell, Rockville, v.2, p.1157-1170, 1990.

CAETANO-ANOLLÉS, G., BASSAM, B.J., GRESSHOFF, P.M. Primer-template interactions during DNA amplification fingerprinting with single arbitrary oligonucleotides. Molecular and General Genetics, Berlin, v.235, p.157-165, 1992.

CHRISTIANSEN-WENIGER， C., VANDERLEYDEN， J Ammonium-excreting Azospirillum sp. become intracellularly established in maize (Zea mays) para-nodules. Biology and Fertility of Soils, Berlin, v.17, p.1-8, 1993.

DE LORENZO, V., HERRERO, M., JAKUBZIK, U., et al. Mini-Tn5 transposon derivatives for insertion mutagenesis, promoter probing, and chromosomal insertion of cloned DNA in gram-negative Eubacteria. Journal of Bacteriology, Washington, v.172, p.6568-6572, 1990.

DE WEGER, L.A., DEKKERS, L.C., VAN DER BIJ, A.J., et al. Use of phosphate-reporter bacteria to study phsphate limitation in the rhizosphere and in bulk soil. Molecular Plant-Microbe Interactions, Saint Paul, v.7, p.32-38, 1994.

DRAHOS, D.J., HEMMING, B.C., MCPHERSON, S. Traking recombinant organism in the environment. $\beta$-galactosidase as a selective marker for fluorescent pseudomonas. Biotechnology, New York, v.4, p.439-444, 1986.

HERRERO, M., DE LORENZO, V., TIMMIS, K.T. Transposon vectors containing non-antibiotic resistance selection markers for cloning and stable chromosome insertion of foreign denes in gram-negative bacteria. Journal of Bacteriology, Washington, v.172, p.6557-6567, 1990.

HUREK, T., REINHOLD-HUREK, B., VAN MONTAGU, M., et al. Root colonization and systemic spreading of Azoarcus sp. strain $\mathrm{BH} 72$ in grasses. Journal of Bacteriology, Washington, v.176, p.1913-1923, 1994.

JEFFERSON, R.A. Assaying chimeric genes in plants: The GUS fusion system. Plant Molecular Biology Reporter, Dordrecht, v.5, n.4, p.387-405,1987.

JEFFERSON, R.A. The GUS reporter gene system. Nature, London, v.342, p.837-838, 1989 .

JEFFERSON, R.A., BURGESS, S.M., HIRSH, D. $\beta$ Glucuronidase from Escherichia coli as a gene fusion marker. Proceedings of the Soil Science Society of America, Madison, v.86, p.8447-8451, 1986. 
JEFFERSON, R.A., KAVANAGH, T.A., BEVAN, M.W. GUS fusions: $\beta$-glucuronidase as a sensitive and versatile gene fusion marker in higher plants. EMBO Journal, Oxford, v.6, p.3901-3907, 1987.

KATUPITIYA, S., NEW, P.B., ELMERICH, C., et al. Improved $\mathrm{N}_{2}$ fixation in 2,4-D-treated wheat roots associated with $A$ lipoferum: studies of colonization using reporter genes. Soil Biology and Biochemistry, Oxford, v.27, p.447-452, 1995.

LAGUERRE, G., MAZURIER, S.I., AMARGER, N. Plasmid profiles and restriction fragment length polymorphism of Rhizobium leguminosarum bv. viciae in field populations. FEMS Microbiology Ecology, Amsterdam, v.101, p.17-26, 1992.

LAM, S.T., ELLIS, D.M., LIGON, J.M. Genetic approaches for studying rhizosphere colonization. Plant and Soil, Dordrecht, v.129, p.11-18, 1990 .

MERCANTE, F.M., FRANCO, A.A. Expressão dos genes nod de Rhizobium tropici, $\boldsymbol{R}$. etli e $\boldsymbol{R}$. leguminosarum bv. phaseoli e estabelecimento da nodulação do feijoeiro na presença de exsudatos de sementes de Mimosa flocculosa e Leucaena leucocephala. Revista Brasileira de Ciência do Solo, Viçosa, 1999 (No prelo).

MERCANTE, F.M. Diversidade genética de rizóbio que nodula o feijoeiro e troca de sinais moleculares na simbiose com plantas hospedeiras. Seropédica-RJ, 1997. 199p. Tese (Doutorado em Agronomia) - Curso de Pós-graduação em Ciência do Solo, Universidade Federal Rural do Rio de Janeiro, 1997.

MERCANTE, F.M., CUNHA, C.O., STRALIOTTO, R., $\boldsymbol{e}$ t al. Efeito do nitrogênio mineral na troca de sinais moleculares durante o processo de infecção das raízes do feijoeiro por Rhizobium. In: CONGRESSO BRASILEIRO DE CIENNCIA DO SOLO, 25, 1995, Viçosa, MG. Resumos... Viçosa : Sociedade Brasileira de Ciência do Solo, 1995. v.1. 549p. p.495-497.

REIS, V.M. Métodos bio-moleculares aplicados na caracterização e detecção de bactérias. Seropédica EMBRAPA-CNPAB, 1996. 26p. (EMBRAPA-CNPAB. Documentos, 28).

REUBER, T.L., LONG, S.L., WALKER, G.C. Regulation of Rhizobium meliloti exo genes in free-living cells and in plant examined using TnphoA fusions. Journal of Bacteriology, Washington, v.173, p.426-434, 1991.

SAIKI, R.K., GELFAND, D.H., STOFFEL, S., et al. Primerdirected enzymatic amplification of DNA with a thermostable DNA polymerase. Science, Washington, v.239, p.487-491, 1988

SAYLER, G.S., NIKBAKHT, K., FLEMING, J.T., et al. Applications of molecular techniques to soil biochemistry. In STOTZKY, G., BOLlAG, J. M. (eds). Soil biochemistry. New York : Marcel Dekker, 1992. v.7. p.131-172.

SESSITSCH, A., HARDARSON, G., DE VOS, W.M., et al. Use of marker genes in competition studies of Rhizobium. Plant and Soil, Dordrecht, v.204, p.35-45, 1998.

SHARMA, S.B., SIGNER, E.R. Temporal and spatial regulation of the symbiotic genes of Rhizobium meliloti in plant revealed by transposon Tn5-gusA. Genes and Development, New York, v.4, p.344-356, 1990

STEFFAN, R.J., ATLAS, R.M. Polymerase chain reaction: applications in environmental microbiology. Annual Review of Microbiology, Palo Alto, v.45, p.137-161, 1991

STRALIOTTO, R., CUNHA, C.O., MERCANTE, F.M., et al. Effect of combined nitrogen on rhizobia-bean (Phaseolus vulgaris) symbiosis evaluated by the $\beta$-glucuronidase activity of a nodABC::gusA fusion. In: INTERNATIONAL SYMPOSIUM ON MICROBIAL ECOLOGY, 7, 1995. Resumos... Santos : Sociedade Brasileira de Microbiologia, 1995. 216p. p.141.

STREIT, W., KOSCH, K., WERNER, D. Nodulation competitiveness of Rhizobium leguminosarum bv. phaseoli and Rhizobium tropici strains measured by glucuronidase (GUS) gene fusions. Biology and Fertility of Soils, Berlin, v.14, p.140-144, 1992

VAN DEN EEDE, G., DEBLAERE, R., GOETHALS, K., $\boldsymbol{e}$ t al. Broad host range and promoter selection vectors for bacteria that interact with plants. Molecular Plant-Microbe Interactions, Saint Paul, v.5, n.3, p.228-234, 1992.

WEINSTEIN, M., ROBERTS, R.C., HELINSKI, D.R. A region of the broad-host-range plasmid RK2 causes stable in plant inheritance of plasmids in Rhizobium meliloti cells isolated from alfalfa root nodules. Journal of Bacteriology, Washington, v.174, p.7486-7489, 1992.

WILSON, K.J. Molecular techniques for the study of rhizobial ecology in the field. Soil Biology and Biochemistry, Oxford, v.27, n.4/5, p.501-514, 1995 .

WILSON, K.J., GILLER, K.E., JEFFERSON, R.A. $\beta$ Glucuronidase (GUS) operon fusions as a tools for studying plant-microbe interactions. In: HENNECKE, H.; VERMA, D. P. S., (eds). Advances in molecular genetics of plantmicrobe interactions. Dordrecht : Kluwer, 1991. p.226-229.

WILSON, K.J., HUGHES, S.G., JEFFERSON, R. The Escherichia coli gus operon: introduction and expression of the gus operon in E. coli and the occorrence and use of GUS in other bacteria. In: GALLAGHER, S. R., (ed). Gus protocols, using the gus gene as a reporter of gene expression. Oxford : Academic, 1992. p.7-22.

WILSON, K.J., SESSITSCH, A., AKKERMANS, A.D.L. Molecular marchers as tools to study the ecology of microrganisms. In: K. RITZ, DIGHTON, J., GILLER, K. E., (eds). Beyond the biomass: composition and function analysis of soil microbial communities. Chichester : John Wiley, 1994. p.149-156.

WILSON, K.J., SESSITSCH, A., CORBO, J.C., et al. $\beta$ Glucuronidase (GUS) transposons for ecological and genetic studies of rhizobia and other Gram-negative bacteria. Microbiology, New York, v.141, p.1691-1705, 1995.

WILSON, K. J., SESSITSCH, A., PARRA, A., BECK, D. Biología molecular en el campo: genes marcadores para a visualización rápida y precisa de la competición entre cepas rhizobianas y la colonización por bacterias de raíces de plantas. In: J. PIJNENBORG, RUÍZ, D., SILES, W., (eds). REUNIÓN LATINOAMERICANA DE RHIZOBIOLOGÍA, 18, 1996, Santa Cruz de la Sierra. Anais... Santa Cruz de la Sierra, 1996. 547p. p.147-162.

YOUNG, J.P.W., DOWNER, H.L., EARDLY, B.D. Phylogeny of the phototropic Rhizobium strain BTAil by polymerase chain reaction-based sequencing of a $16 \mathrm{~S}$ rRNA gene segment. Journal of Bacteriology, Washington, v.173, p.2271-2277, 1991. 